\title{
APLIKASI SISTEM INFORMASI GEOGRAFIS DALAM PENENTUAN LOKASI BUDIDAYA RUMPUT LAUT DI PESISIR KECAMATAN SUPPA, KABUPATEN PINRANG
}

\section{Application of Geographic Information Systems in Determining Sea Grass Cultivation Location in Suppa District Coast, Pinrang Regency}

Oleh:

\author{
Damis $^{1 *}$, Surianti ${ }^{1}$, Hasrianti $^{1}$, A. Rini Sahni Putri ${ }^{1}$, Asmidar $^{2}$ \\ ${ }^{1}$ Fakultas Sains dan Teknologi, Universitas Muhammadiyah \\ Sidenreng Rappang, Indonesia \\ ${ }^{2}$ Fakultas Perikanan dan Ilmu Kelautan, Universitas Muslim \\ Indonesia, Indonesia \\ *Korespondensi penulis: damis.jumardi@gmail.com
}

\begin{abstract}
ABSTRAK
Penentuan lokasi budidaya rumput laut menggunakan aplikasi sistem informasi geografis di wilayah pesisir Kecamatan Suppa. Penelitian ini dilaksanakan berkisar sepuluh bulan pada tahun 2020. Tujuan penelitian ini adalah untuk menentukan kesesuain lahan pada budidaya rumput laut dengan menggunakan aplikasi 'Sistem Informasi Geografis'. Penelitian ini memiliki karakteristik lahan sebagai penyusun kualitas lahan untuk budidaya rumput laut yaitu: tinggi gelombang, kecepatan arus, pasang surut, kedalaman, kekeruhan, suhu, salinitas, $\mathrm{pH}$, nitrat dan fosfat. Penelitian ini memiliki tujuan sebagai bahan informasi dalam usaha perbaikan kualitas dan rencana pengelolaan ekosistem pesisir secara terpadu dan berkelanjutan terhadap pengambil kebijakan dalam hal ini pemerintah setempat serta memberikan gambaran tentang pentingnya budidaya rumput laut di wilayah pesisir. Adapun hasil analisis data spasial lokasi kesesuaian lahan budidaya rumput laut yang memiliki golongan sesuai $\pm 996,63$ Hektar dan tidak sesuai $\pm 361,25$ Hektar oleh sebab itu sangat baik dilakukan budidaya rumput laut dengan luas wilayah sangat tinggi memungkinkan dilakukan budidaya rumput laut berbasis lingkungan.
\end{abstract}

Kata kunci: kesesuaian, lahan, budidaya, rumput laut

\begin{abstract}
Determining location of seaweed cultivation using geographic information system application in the coastal area of Suppa District. The length of this research was carried out around ten months in 2020. The purpose of this study was to determine the suitability of land for seaweed cultivation using 'Geographic Information System' application. This research has land characteristics as a constituent of land quality for seaweed cultivation, namely: wave height, current velocity, tides, depth, turbidity, temperature, salinity, $\mathrm{pH}$, nitrate and phosphate. This study aims to provide information for quality improvement efforts and a coastal ecosystem management plan in an integrated and sustainable manner to policy makers, in this case the local government, and to provide an overview of the importance of seaweed cultivation in coastal areas. The results of the spatial data analysis of the location of the suitability of seaweed cultivation land which have the appropriate group of \pm 996.63 hectares and not suitable for \pm 361.25 hectares, therefore it is very good to do seaweed cultivation with a very high area.
\end{abstract}

Key words: suitability, land, cultivation, seaweed 


\section{PENDAHULUAN}

Kawasan pesisir Kabupaten Pinrang merupakan salah satu wilayah pesisir di Indonesia yang memiliki potensi besar. Adanya ancaman ekologis dan rawan terjadinya berbagai konflik sosial ekonomi, maka penataan ruang dan pengelolaan dengan baik dan bijaksana menjadi sangat penting untuk dilakukan (Supriharyono 2000). Wilayah pesisir ini memiliki sumberdaya perairan yang cukup potensial untuk pengembangan budidaya laut seperti budidaya ikan sistem karamba jaring apung (KJA), budidaya rumput laut dan budidaya kerang mutiara. Indonesia memiliki garis pantai terpanjang kedua dunia, hal ini memberikan kesempatan budidaya rumput laut untuk terus dikembangkan terutama dengan karakteristik perairan pantai yang dangkal (Radiarta et al. 2007). Berdasarkan data produksi rumput laut (FAO 2007) menunjukkan adanya kenaikan produksi rumput laut dari 102.000 ton pada tahun 1994 meningkat menjadi 866.000 ton pada tahun 2005. Pengembangan budidaya rumput laut tidak terlepas dari beberapa permasalahan yang disebabkan oleh pemanfaatan kawasan budidaya rumput laut oleh sebab itu perlu dilakukan penentuan lokasi budidaya rumput laut yang berbasis kesesuaian lahan dan dapat mengatur pola tanam budidaya rumput laut dan aktivitas perikanan lainya (Widodo 2001). Pemanfaatan lokasi budidaya rumput laut sebagai sumberdaya perairan yang dimanfaatkan untuk kepentingan usaha nelayan pembudidaya, maka dalam hal ini diperlukan suatu kajian dalam menentukan lokasi budidaya yang sesuai bagi pelaku budidaya rumput laut yang berbasis kesesuaian lahan (Kangkan et al. 2007). Pemilihan lokasi budidaya yang tepat merupakan salah satu faktor yang sangat penting dalam menentukan kelayakan suatu usaha budidaya dengan peluang keberhasilan yang lebih besar (Sukandi 2002).

Menurut (Legovic T. et al. 2008) daya dukung dapat diartikan sebagai produksi maksimum dari suatu spesies atau suatu populasi yang dapat ditampung oleh ekosistem. (McKindsey CW et al. 2006) juga menambahkan bahwa daya dukung terbagi atas empat, yaitu fisik, produksi, ekologi, dan sosial. Menurut (Prahasta 2011) pemanfaatan data satelit penginderaan jauh sangat berpotensi untuk dipergunakan dalam kajian dan penentuan lokasi budidaya rumput laut dengan informasinya yang terbaru dan akurat serta cakupannya yang luas, serta dapat digunakan dalam identifikasi kesesuaian lahan pada suatu wilayah kemampuan ini merupakan salah satu kelebihan aplikasi SIG dibandingkan dengan menggunakan analisis secara tekstual.

Tujuan Penelitian ini adalah penentuan lokasi budidaya rumput laut yang sesuai dengan menggunakan aplikasi SIG (Sistem Informasi Geografis). Serta penerapan aplikasi SIG yang memiliki ouput dapat menghasilkan kesesuaian pemanfaatan lahan wilayah pesisir pada masing-masing aktivitas guna lahan serta pengelolaan wilayah pesisir yang ada di wilayah pesisir Pinrang dengan dilakukannya penentuan lokasi budidaya rumput laut hal tersebut sangat baik untuk pelaku pembudidaya rumput laut dan berdampak dengan baik terhadap pengembangan pemanfaatan wilayah pesisir dimasa yang akan datang.

\section{METODE PENELITIAN}

Penelitian ini terlaksanakan selama lebih sepuluh bulan pada tahun 2020 yang berada di wilayah pesisir Kecamatan Suppa, Kabupaten Pinrang. Peta lokasi penelitian dapat dilihat pada Gambar 1. Data kualitas air yang diambil pada saat pengambilan data secara langsung dilokasi penelitian kawasan pesisir kecamatan Suppa di antaranya parameter salinitas, suhu, arus, pH, DO, kecerahan, kedalaman serta parameter yang dianalisis melalui laboratorium yaitu parameter nitrat dan fosfat. 


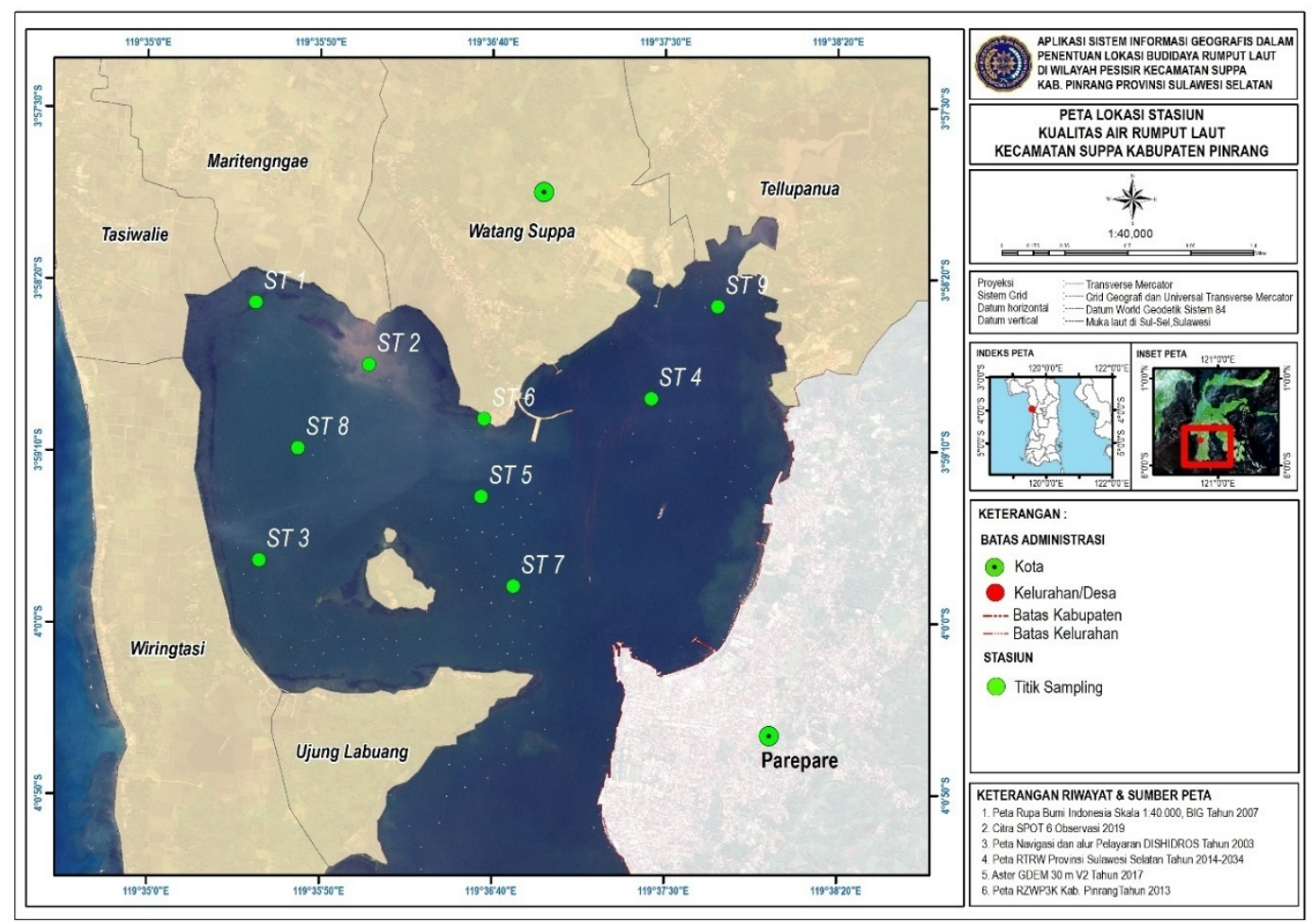

Gambar 1 Peta Lokasi Penelitian

Analisis kualitas air yang dilakukan merupakan bagian dari tahapan penelitian untuk melihat parameter kualitas air pada lokasi budidaya rumput laut serta menentukan lokasi yang sesuai dilakukan aktivitas budidaya rumput laut di wilayah pesisir tepatnya pada Kecamatan Suppa Kabupaten Pinrang. Semua parameter akan diolah menggunakan aplikasi SIG yang merupakan salah satu alat yang dapat digunakan untuk melakukan identifikasi lahan dan dapat menentukan luas wilayah serta dapat menentukan kesesuaian lahan.

Analisis kesesuaian lahan ditentukan melalui sistem pembobotan dan skoring terhadap faktor pembatas/parameternya. Sistem pembobotan terhadap faktor pembatas merupakan kriteria potensi lahan yang ditentukan berdasarkan tingkat dominasi dari faktor pembatas terhadap peruntukan lahan. Jadi pembobotan dimaksudkan untuk memberikan perbedaan besar kecilnya pengaruh parameter yang satu dengan yang lainnya terhadap tingkat kesesuaiannya (Sulma et al. 2005). Dalam menentukan tingkat kesesuaian lahan budidaya rumput laut dilakukan penyusunan matrik kesesuaian berdasarkan skoring dan pembobotan dengan mengambil beberapa parameter dengan menggunakan teknik overlay bertingkat serta pembobotan dalam menentukan tingkat kesesuaian.

\section{HASIL DAN PEMBAHASAN}

Secara geografis Kabupaten Pinrang terletak pada lintang $118^{\circ} 10^{\prime}$ BT- $119^{\circ} 30^{\prime}$ BT dan $3^{\circ} 30^{\prime}$ LS$4^{0} 10^{\prime} \mathrm{LU}$, terdiri atas 12 kecamatan, 65 desa dan 39 kelurahan. Wilayah kecamatan di Kabupaten Pinrang yang terletak di sepanjang pesisir adalah Kecamatan Suppa, Mattiro Sompe, Lanrisang, Cempa, Duampanua, Lembang dengan panjang garis pantai kurang lebih $101 \mathrm{~km}$. Secara administrasi daerah ini berbatasan dengan: sebelah utara: Kabupaten Polmas dan Tana Toraja, sebelah timur: Kabupaten Sidrap dan Enrekang, sebelah barat Selat Makassar, sebelah selatan: Kota Parepare. Luas wilayah keseluruhan Kabupaten Pinrang adalah 1.961,77 km² atau 3,14 \% dari luas wilayah Sulawesi Selatan. 
Sedangkan luas wilayah kecamatan pesisir adalah $1.457,19 \mathrm{~km}^{2}$ atau $74,27 \%$ dari seluruh luas Kabupaten Pinrang.

Kabupaten Pinrang memiliki dua macam/jenis angin yaitu angin barat dan angin timur. Angin barat cenderung mengandung curah hujan (bersifat basah). Sedangkan angin timur bersifat kering yang intensitas curah hujan yang lebih sedikit. Curah hujan terbesar pada umumnya terjadi pada bulan April dan hujan terkecil pada bulan Agustus. Sedangkan musim penghujan umumnya berlangsung mulai dari bulan November sampai April dan musim kemarau mulai dari bulan Juni sampai Oktober. Intensitas rata-rata cura hujan di wilayah Pinrang berkisar 2.500-3.000 mm/tahun. Evaporasi rata-rata tahunan berkisar antara 5,5-8,7 mm/hari. Tingkat kesuburan tanah/lahan sangat subur 443,50 ha, tanah/lahan yang tingkat kesuburannya sedang 148,88 ha dan tanah/lahan yang tidak subur atau kritis 248,70 ha.

\section{Analisis Kualitas Air pada Lokasi Budidaya Rumput Laut}

Hasil pengamatan dan pengukuran di perairan wilayah pesisir Kecamatan Suppa, Kabupaten Pinrang masuk dalam kriteria sesuai yang berdasarkan maktriks kesesuaian budidaya rumput laut untuk pertumbuhan rumput laut. Hasil analisis laboratorium kesesuaian lahan budidaya rumput laut di wilayah pesisir Pinrang dapat dilihat pada Tabel 1.

Tabel 1. Persentasi Nilai Kesesuaian Lahan Budidaya Rumput Laut di Wilayah Kecamatan Suppa

\begin{tabular}{ccccccccc}
\hline \multirow{2}{*}{ Stasiun } & \multicolumn{7}{c}{ Fisika dan Kimia Perairan } \\
\cline { 2 - 9 } & Suhu & Salinitas & DO & pH & Arus & Kecerahan & Nitrat & Fosfat \\
\hline 1 & 31.5 & 37 & 6.50 & 8.21 & 0,3 & 40 & 0.004 & 0.00023 \\
2 & 30.7 & 35 & 6.49 & 8.28 & 0,4 & 50 & 0.005 & 0.00030 \\
3 & 31.2 & 37 & 6.33 & 8.44 & 0,39 & 50 & 0.005 & 0.00021 \\
4 & 29.8 & 35 & 6.53 & 8.32 & 0,5 & 80 & 0.005 & 0.00032 \\
5 & 29.3 & 36 & 6.50 & 8.28 & 0,3 & 80 & 0.005 & 0.00021 \\
6 & 30.5 & 37 & 6.33 & 8.21 & 0,6 & 40 & 0.004 & 0.00023 \\
7 & 30.2 & 35 & 6.48 & 8.44 & 0,3 & 80 & 0.005 & 0.00030 \\
8 & 31.0 & 37 & 6.35 & 8.32 & 0,5 & 50 & 0.005 & 0.00032 \\
9 & 30.0 & 36 & 6.49 & 8.21 & 0,3 & 50 & 0.005 & 0.00023 \\
\hline RATA-RATA & 30.4 & 36 & 6.44 & 8.30 & 0,35 & 58 & 0.005 & 0.00026 \\
\hline
\end{tabular}

Sumber: hasil analisis (2020)

Berdasarkan persentasi pada parameter fisika dan kimia diketahui nilai rata-rata setiap parameter adalah suhu $30^{\circ} \mathrm{C}$, salinitas $36 \mathrm{ppt}$, DO 6,44 ppm, $\mathrm{pH} 8,30$, arus $0,35 \mathrm{~m} / \mathrm{s}$, kecerahan $58 \%$, nitrat $0,005 \mathrm{mg} / \mathrm{l}$, dan fosfat $0,00026 \mathrm{ppm}$. Analisis kesesuaian lahan budidaya rumput laut memiliki hasil keseuaian lahan budidaya rumput laut yang diketahui yang sesuai $\pm 996,63$ ha dan tidak sesuai $\pm 361,25$ ha. Berdasarkan hasil pemetaan ruang menunjukkan penyebaran kelas sebagai berikut:

1. Termasuk dalam kelas sesuai (S) seluas \pm 996.63 ha. Mengacu pada stasiun pengambilan sampel yang berada di wilayah Kecamatan Suppa.

2. Lokasi yang termasuk ke dalam kelas yang tidak sesuai (N) seluas $\pm 361,25$ ha mengacu pada stasiun pengambilan sampel, maka perairan yang memiliki kelas tidak sesuai.

Kawasan sesuai (S) dicirikan sebagai kelas yang tidak memiliki faktor pembatas yang berarti jika perairan tersebut dikembangkan untuk budidaya rumput laut secara lestari. Pada konteks pengelolaan secara umum, kondisi perairan wilayah pesisir Kecamatan Suppa, Kabupaten Pinrang di kawasan yang sesuai memiliki kualitas yang baik untuk budidaya rumput laut, baik untuk parameter fisika, kimia, maupun biologi perairan. 
Kawasan tidak sesuai $(\mathrm{N})$ dicirikan dengan adanya faktor pembatas yang bersifat permanen sehingga disarankan untuk dibiarkan tanpa dikelola untuk budidaya rumput laut atau dikelola secara alami untuk biota yang memerlukan kondisi perairan yang sesuai. Secara umum, salah satu faktor pembatas pada kawasan ini adalah kedalaman, terutama pada kawasan tidak sesuai yang berada di perairan Kota Parepare. Untuk melihat luasan kesesuaian lokasi budidaya rumput laut pada kluster perairan pesisir wilayah pesisir dapat dilihat pada Gambar 2.

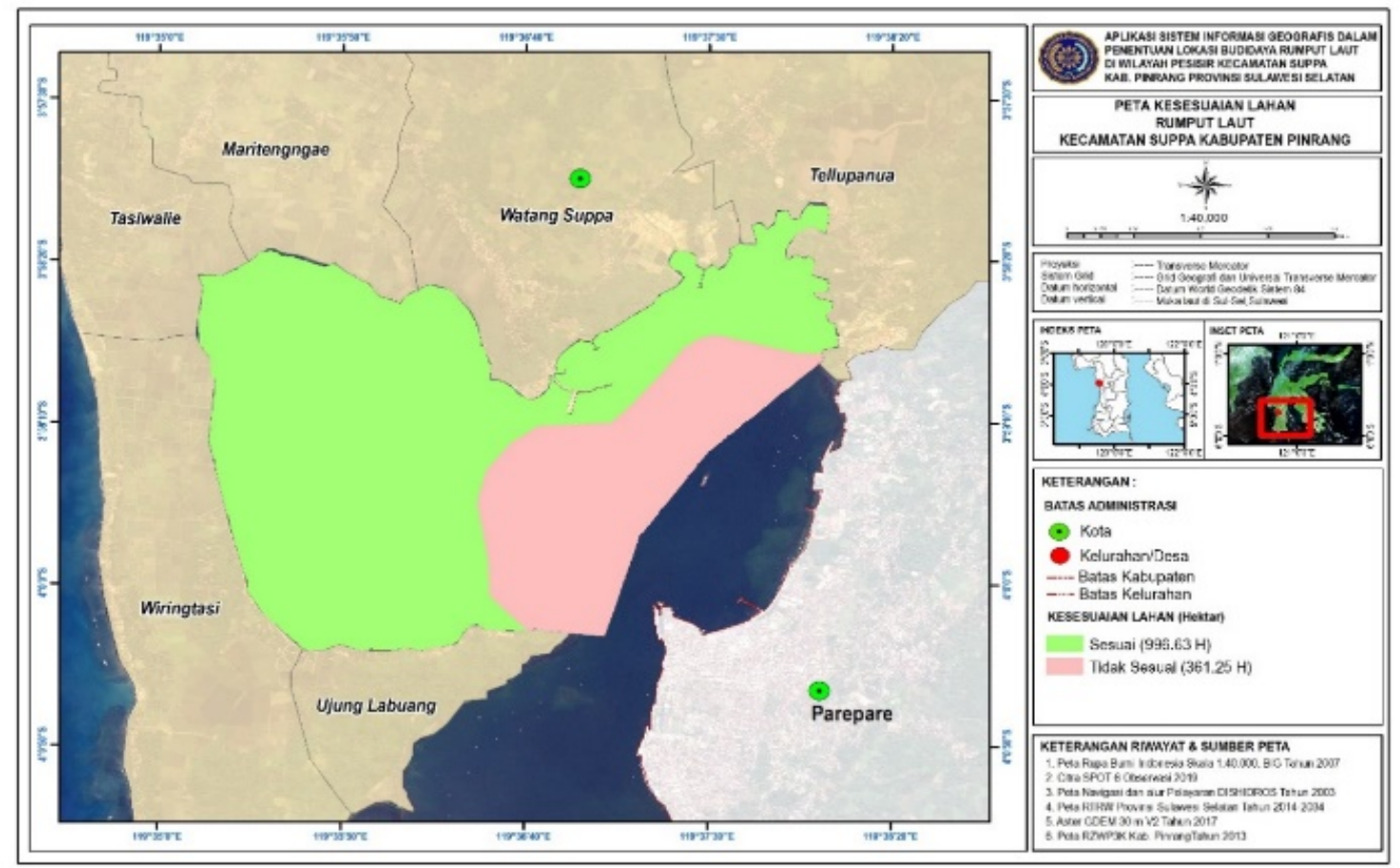

Gambar 2 Peta Sebaran Kesesuaian Lahan Budidaya Rumput Laut

\section{KESIMPULAN DAN SARAN}

Berdasarkan hasil analisis data spasial lokasi kesesuaian lahan budidaya rumput laut yang memiliki golongan sesuai $\pm 996,63$ hektar dan tidak sesuai $\pm 361,25$ hektar oleh sebab itu sangat baik dilakukan budidaya rumput laut dengan luas wilayah sangat tinggi memungkinkan dilakukan budidaya rumput laut berbasis lingkungan.

\section{UCAPAN TERIMA KASIH}

Penulis mengucapkan terima kasih kepada DRPM KEMENRISTEK-DIKTI karena telah membantu dalam pendanaan dan kepada dosen dan staf Fakultas Sains dan Teknologi Universitas Muhammadiyah Sidenreng Rappang yang selalu memberikan motivasi sehingga penelitian ini terlaksana dengan baik.

\section{DAFTAR PUSTAKA}

FAO. 2007. Globalaquacultureproduction search. <http://www.fao.org/>. [diunduh pada 09 Juni 2020]

Kangkan AL, Agus H, Suminto. 2007. Studi PenentuanLokasi untuk Pengembangan Budidaya Laut Berdasakan Parameter Fisika, Kimia dan Biologi di Teluk Kupang, Nusa Tenggara Timur. Jurnal Pasir Laut. 3(1): 76-93. 
Legovic T, Palerud R, Christensen G, White P, Regpala R. 2008. Amodeltoestimate Aquaculture Carrying Capacity in Three Areas of the Philippines. Science Diliman. 20(2): 31-40.

McKindsey CW, Thetmeyer H, Landry T, Silvert W. 2006. Review of Recent Carrying Capacity Models Forbivalve Culture And Recommendations for Research and Management. Aquaculture. 261(2): 451-462.

Prahasta E. 2011. Tutorial ArcGIS Dekstop Untuk Bidang Geodesi dan Geomatika. Informatika. Bandung.

Radiarta IN, Tri HP, Adang S, Joni H, Ofri J. 2007. Penentuan Lokasi Budidaya Rumput Laut (Euchema spp.) Berdasarkan Parameter Lingkungan di Perairan Kecamatan Moro, Provinsi Kepulauan Riau. J. Ris. Akuakultur. 2(3): 319-328.

Sukandi MF. 2002. Peningkatan Teknologi Budidaya Perikanan. Jurnal Iktiologi Indonesia. 2(2): 61-66.

Sulma SB, Hasyim A, Susanto dan Budiono. 2005. Pemanfaatan Penginderaan Jauh Untuk Penentuan Kesesuaian Lokasi Budidaya Rumput Laut di Kepulauan Seribu. Lembaga Penerbangan dan Antariksa Nasional (LAPAN). Jakarta.

Supriharyono. 2000. Pelestarian dan Pengelolaan Sumberdaya Alam di Wilayah Pesisir. PT.Gramedia Pustaka Utama. Jakarta.

Widodo J. 2001. Prinsip Dasar Pengembangan Akuakultur dengan Contoh Budidaya Kerapu dan Bandeng di Indonesia. Teknologi Budidaya Laut dan Pengembangan Sea Farming Indonesia. Departemen Kelautan dan Perikanan dan JICA. Jakarta. 